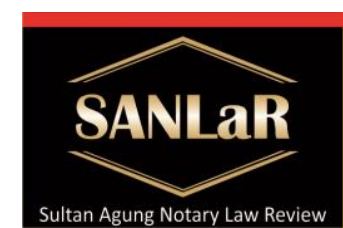

Volume 2 No. 4, December 2020
Sultan Aqung

Notary Law Review

ISSN 2686-4428

published b Faculty of Law Universitas Islam Sultan Agung Purchase and Binding Agreement...( Andi Rosita)

\title{
Purchase and Binding Agreement as a Production Guarantee of Attorney to Impose Mortgage Rights
}

\author{
Andi Rosita*), Amin Purnawan ${ }^{* *}$ and Akhmad Khisni ${ }^{* * *}$ \\ *) Student Master of Notary Law, Faculty of Law, Universitas Islam Sultan Agung \\ Semarang, Indonesia, E-mail: andirosita.not@gmail.com \\ $\left.{ }^{* *}\right)$ Lecturer Master of Notary Law, Faculty of Law, Universitas Islam Sultan Agung \\ Semarang, Indonesia \\ ${ }^{* * *)}$ Lecturer Master of Notary Law, Faculty of Law, Universitas Islam Sultan Agung \\ Semarang, Indonesia
}

\begin{abstract}
This study aims to find out whether the Sale and Purchase Agreement can be used as a guarantee for the making of a power of attorney to impose mortgage rights. The approach method in this research is normative law, the data source is obtained from the literature and the legal materials used are primary, secondary and tertiary legal materials which are then analyzed by means of qualitative analysis. Based on the results of data analysis, it is concluded that the sale and purchase agreement is a manifestation of the principle of freedom of contract in which the parties are free to make any kind of agreement they want as contained in Article 1338 of the Civil Code by stating that all agreements made legally are valid as law for those who make them. However, the sale and purchase agreement cannot be used as a guarantee in making the deed of power of attorney to impose mortgage rights because if the land rights process has not been completed and the SKMHT period has ended later the debtor is in default, the SKMHT is null and void and the land object which is still in the status of a sale and purchase agreement cannot be subject to security rights and the deed of power of attorney imposing mortgage rights (SKMHT) cannot be upgraded to deed of granting mortgage rights (APHT) which is executorial in nature. The validity period of SKMHT for land that has been registered is one (1) month and creditors have the potential to lose the opportunity to impose mortgage rights.
\end{abstract}

Keywords: Agreement; Guarantee; Mortgage.

\section{Introduction}

Banking credit has a crucial function in terms of financing the national economy and as a means of driving economic growth. In the economy and trade, credit can increase the usability of money, increase the circulation and traffic of money or goods as a means of economic stability, increase economic enthusiasm or increase income. ${ }^{1}$ Therefore credit facilities are not only intended for individual people as small

\footnotetext{
${ }^{1}$ Thomas Suyatno et, al. (1993). Credit Basics. Jakarta: 3rd ed., p. 16
} 
entrepreneurs who need capital but also for large entrepreneurs and companies with legal status to develop businesses or improve their standard of living.

The enthusiasm of banks in extending credit is also accompanied by risks that will arise in the future, so that in its implementation, banks must pay attention to sound credit principles. To reduce this risk, credit guarantee in the sense of confidence in the ability and ability of the debtor to pay off his debt as promised is an important factor that must be considered by the bank. ${ }^{2}$ Among them are the factors of ability and willingness, prudence by maintaining the element of security and at the same time the element of profit (profitability) of a credit. ${ }^{3}$ This is very important to do because high lending can lead to a decline in lending standards.

Before the provision of credit is carried out, the bank ensures that all juridical aspects related to credit have been resolved and are believed to provide adequate protection for the bank. ${ }^{4}$ that is, by means of credit, it must be stated in writing, both deeds under the hands which are sufficiently stamped and notary deeds which are also contained in the State Gazette of the Republic of Indonesia number 42 / POJK.03 / 2017 concerning Obligations to Prepare and Implement Bank Credit Policies for Commercial Banks, article 2 which states that the bank is required to have written bank credit or financing. 5

Even though it has been arranged in such a way as to provide solutions to avoid unwanted things such as defaults, in practice the implementation of bank credit agreements does not always run smoothly but there are various kinds of obstacles encountered in the field including certificates that are still bound by other documents, not yet mapped digitally, is in the process of solving, the process of changing the name from the seller to the buyer as a potential debtor of a bank, and so on. For this reason, the certificate cannot be registered immediately because it has to wait for the certificate completion process and on the other hand, the bank must immediately disburse credit funds to the debtor. Furthermore, at the will of the bank, The Official for Making Land Deeds (PPAT) makes a deed of power of attorney to impose mortgage rights (SKMHT) which contains the debtor authorizing the bank to charge mortgage rights when the certificate has been processed but the debtor is unable to attend. In short, this SKMHT is irrevocable unless with the consent of both parties, the validity period has ended, the power issued by has been exercised, or if it is canceled by the court. ${ }^{6}$

From the results of preliminary observations with interview techniques at the head of the unit of Bank Mandiri (Persero) Tbk, in Kendari City, it was stated that the bank still accepts customers who apply for credit with a guaranteed sale and purchase agreement (PPJB) made at a local notary, because of this right still in the process of transferring rights at the National Land Agency office. Then, the bank wants to make a power of attorney to first impose mortgage rights (SKMHT) by the Land Deed Making Official for the purpose of credit disbursement.

\footnotetext{
${ }^{2}$ Wijanarto (1997). Banking Law and Regulations in Indonesia. Jakarta: 3rd ed., p. 10

${ }^{3}$ Muhammad Djumhana (1993). Banking Law in Indonesia. Bandung: p. 175

${ }^{4}$ Rachmadi Usman (2001). Banking Law Aspects in Indonesia, Bandung: p. 264

${ }^{5}$ http://ditjenpp.kemenkumham.go.id/arsip/In/2017/ojk42-2017bt.pdf accessed on October 28, 2020

${ }^{6}$ Rachmadi Usman (2001). Banking Law Aspects in Indonesia, Bandung: p. 264
} 
To strengthen this writing, based on the background description above, the writer found previous studies that had conducted an earlier study of the SKMHT credit agreement, namely the research entitled Legal Implications of Using a Power of Attorney Imposing Mortgage as Collateral in a Home Ownership Credit Agreement using qualitative research methods with a socio legal approach. The results of this study indicate that the Mortgage Agreement (KPR) is subject to the imposition of a lot of Mortgage Rights with a Power of Attorney to Impose Mortgage Rights (SKMHT) without being followed up with a Deed of Granting Mortgage Rights, so that if the debtor is in default, the creditor does not have the right to execute. ${ }^{7}$

From what the researchers have done above, it can be understood that the researcher conducted research on the Power of Attorney to impose Mortgage Rights which was not followed by a Deed of Granting Mortgage by using a qualitative research method. The connection with this research is that the author will also discuss SKMHT but from a different side, namely, why SKMHT can be made based on a sale and purchase binding agreement.

\section{Research Methods}

The research method used is normative through a statutory approach with documentary study techniques to obtain primary, secondary and tertiary data and then analyzed with descriptive analytical depiction. ${ }^{8}$

\section{Results and Discussion}

David J Mack in H. Salim and Erlies S. Nurbani's book presents the meaning of a contract, namely:

"An agreement between two or more parties that creates an obligation on all parties to perform (or not perform) a particular action or set of related actions"

This means that a contract is described as an agreement between two or more parties to create a legal obligation for all parties. Contracts or agreements are not only made based on the legal terms of the agreement as stated in article 1320 of the Civil Code, but there are also principles that need to be considered, namely, the principle of freedom of contract, the principle of consensualism, the principle of obligator, the principle of Binding strength (Pacta Sun Servanda), Principle of goodwill, and Principle of Personality. ${ }^{9}$ One form of the principle of freedom of contract in which the parties can enter into any contract or agreement as long as it does not oppose the applicable law, namely the agreement for sale and purchase of land rights.

This is mostly done by parties who agree to transfer their rights. But be aware that Sale and Purchase Agreement is a pre-agreement that needs to be followed up with a sale

\footnotetext{
${ }^{7}$ Badriyah High School, R. Suharto, \& H. Kashadi in Journal, (2019). " Legal Implications of Using a Power of Attorney to Imposes Mortgage as Collateral in the Home Ownership Credit Agreement "in Law, Development \& Justice Review, Vol. 2, No. 1 May 2019. url https://ejournal2.undip.ac.id/index.php/lj/article/view/5140 accessed on 28 October 2020

${ }^{8} \mathrm{H}$. Halim HS \& Erlies S. Nurbani. (2013). application of legal theory in thesis and dissertation research. Jakarta: Raja Grafindo Persada. p. 17-18

${ }^{9}$ Munir Fuady, Contract Law (2003). From a Business Point of View, Bandung: PT Citra Aditya Bakti. p. 5
} 
and purchase deed agreement to transfer ownership of the object made by the Land Deed Making Official. Sale and purchase agreement including din the scope of the agreement law, while the sale and purchase is included in the scope of the national land law which is subject to the Basic Agrarian Law and its implementing regulations. ${ }^{10}$ From the research, it was found that a power of attorney to impose mortgage rights was made based on a Sale and Purchase Agreement which in this case could lead to new problems in the future, moreover, the Sale and Purchase Agreement (PPJB) cannot be said of the transfer of rights completely. Normally a Bank can receive objects in the form of land and buildings that can be encumbered with a Mortgage but if the collateral is in the form of a Sale and Purchase Agreement (PPJB), in the event that the land has not transferred these rights and is still in process, the land and building object is legally not yet can be burdened with Mortgage Rights.

The Sale and Purchase Agreement cannot be used as a guarantee for a loan or loan agreement or a debt agreement. ${ }^{11}$ This legal action can be detrimental to the bank as the creditor because if the debtor is in default, if the SKMHT has expired, it is null and void and cannot be followed up by installing a deed of imposition of mortgage rights.

As contained in the Mortgage Rights Law number 4 of 1996 regarding the deadline of the Power of Attorney to Charge Mortgage Rights (SKMHT) which has been signed by both parties, it must be followed up by making a Deed of Granting Mortgage Rights (APHT) within 1 (one) time, months after being given. Power of Attorney to impose mortgage rights (SKMHT) for land rights that have not been registered no later than 3 (three) months after being granted. This period does not apply to certain credits based on applicable laws. For certain loans such as Home Ownership Loans, the term of the Proxy to Charge the Mortgage Rights (SKMHT) is determined by the period of time until the loan agreement expires.

The importance of increasing the status of SKMHT to APHT is useful for obtaining legal certainty for creditors because with APHT certificates, which mortgage rights can be borne Certificates guarantee rights have the same executorial power as the verdict court who have obtained legal force permanent. Mortgage Rights Act Article 13 states that granting Mortgage Rights must be registered at the Land Office. At the latest 7 (seven) working days after the signing of the Deed of Granting Rights, PPAT is obliged to send the Deed of Granting Mortgage concerned and other necessary documents to the Land Office. ${ }^{12}$ Certificate the land title that has been affixed with a note of the imposition of a security right shall be returned to the holder of the land title concerned. The mortgage certificate is handed over to the mortgage holder. ${ }^{13}$

\footnotetext{
10 Maria SW Sumardjono. (1994). Apartment Construction and Its Problems: Judging from a Juridical Point of View Working Paper for Limited Discussion on the Development of Indonesian Consumer Protection Act (Comparative Study and Draft Evaluation). Jakarta: PT. Citra Aditya Bakti. p. 20

${ }^{11}$ https://notarymagazine.com/kupas-tuntas-ppjb-skmht-ht-el/ accessed on 28 October 2020

12 Badriyah High School, R. Suharto, \& H. Kashadi. (2019). "Legal implications of using a power of attorney to impose a mortgage as collateral in the mortgage agreement". in Law, Development \& Justice Review, Volume 2, No 1 May 2019. urlhttps://ejournal2.undip.ac.id/index.php/lj/article/view/5140 accessed on 28 October 2020

13 Yusup Sugiarto \& Gunarto. (2018)"The Role of Notary Public / PPAT in Making Power of Attorney to Charge Mortgage Agreement (Study at Pt. Bank Tabungan Negara Tbk. Cirebon Branch)" in Journal of Deed, Volume 5, No. 1 May 2018. urlhttp://jurnal.unissula.ac.id/index.php/akta/article/view/2525/0
} 
In the banking world, credit disbursement of course requires a credit guarantee as legal protection for the bank itself. before the application for credit is made, the bank first must pay attention to sound credit principles and based on prudential principles and carry out a thorough assessment of all aspects in article 8 of the Banking Act Number 10 of 1998 concerning Amendment to Act No. 7 of 1992 concerning Banking states that what must be assessed by banks before granting credit is the character, ability, capital, collateral and business prospects of debtor customers, which are then known as "the five C's of credit analysis" or the 5 C's principle.

This guarantee must be in accordance with the provisions stipulated in BI Directors Decree No. 23/69 / Kep / Dir dated February 28, 1991. ${ }^{14}$ Credit guarantee is one of the elements of credit extension, which is included in the $5 \mathrm{C}$ elements. The $5 \mathrm{C}$ elements are: ${ }^{15}$

1. Character / profile of customer integrity;

2. Financial capacity / capacity to meet customer obligations;

3. Capital / capital of customers;

4. The overall economic conditions of the customer;

5. Collateral / guarantees for the credit facilities provided.

With regard to collateral, from the results of the research, if the debtor is in default, the bank does not have the right to execute the land because the status is still in the form of a sale and purchase agreement which has not transferred the rights of the seller to the debtor in full due to the transfer of rights to the land by an act. law in the form of sale and purchase according to Article 37 paragraph (1) PP Number 24 of 1997 concerning land registration stipulates that in order to transfer land rights, an authentic deed is required to be drawn up before the official who makes Land deeds (PPAT). ${ }^{16}$

The SKMHT binding on PPJB can be detrimental to the bank because PPJB is only an aid agreement not a principal agreement (sale and purchase), customers who have obtained credit facilities from the bank are not entirely able to return their debts smoothly according to the agreed time. In fact, in practice there are always some customers who cannot return credit to the bank that has borrowed it. As a result of the customer being unable to pay off their debt, it will be illustrated that the credit trip is stopped or stuck. If this happens the bank cannot sell the guarantee based on the PPJB.

Actions against the law, namely default by the debtor, cause a loss that is not expected by the creditor. This is no longer in line with the effectiveness of a statutory regulation which serves as the basis for a bank in carrying out its duties. Providing credit with PPJB guarantees is the same as providing credit without collateral and this is contrary to the principle of prudence in lending which triggers the risk of loss to the bank which results in criminal sanctions for the bank employee concerned as in article 49 of the

accessed on 28 October 2020

14 http://alwesius.blogspot.com/2014/05/ppjb-tidak-dapat-dipakai-sebagai-dasar.html accessed on 29 October 2020

15 https://www.hukumonline.com/klinik/detail/ulasan/lt55d9943725df1/ppjb-sebagai-jaminan-kredit/ accessed on 29 October 2020

${ }^{16}$ Muhammad S. Muldjabar. (2019). principle of good faith in the agreement of sale and purchase of land rights: Surabaya, Media Sahabat Cendekia, p. 197. 
banking law, namely not implementing it steps necessary to ensure bank compliance with this law.

\section{Closing}

Based on the results of the research, it can be concluded that the power of attorney imposing mortgage rights cannot be made based on a sale and purchase agreement even though the PPJB fulfills the elements and legal conditions of an agreement because PPJB is not the main agreement as referred to in the registration of transfer of rights which requires an authentic deed made in before the official land deed maker. Although PPJB is also an authentic deed made by a public official, this is not what is meant by government regulation number 24 of 1997 concerning land registration. The consequences of this legal action can be detrimental to the bank in terms of losing the opportunity to impose mortgage rights if the customer fails to promise so that the bank is said to have not applied the principle of prudence in lending. In a credit agreement that is implemented, it is better if the bank only accepts collateral that has been reversed from the name of the debtor. This is to prevent future uncertainty, because as we know in the sale and purchase agreement, the bank is not the party that participates in the agreement. So that they do not have rights to the land.

\section{References}

Journals:

[1] Badriyah High School, R. Suharto, \& H. Kashadi. (2019). "Legal implications of using a power of attorney to impose a mortgage as collateral in the mortgage agreement". in Law, Development \& Justice Review, Vol ume 2, No 1 May 2019. urlhttps://ejournal2.undip.ac.id/index.php/li/article/view/5140 accessed on 28 October 2020

[2] http://ditjenpp.kemenkumham.go.id/arsip/In/2017/ojk42-2017bt.pdf diakes on October 28, 2020

[3] https://www.hukumonline.com/klinik/detail/ulasan/lt55d9943725df1/ppjbsebagai-jaminan-kredit/ accessed on 29 October 2020

[4] Yusup Sugiarto \& Gunarto. (2018)"The Role of Notary Public / PPAT in Making Power of Attorney to Charge Mortgage Agreement (Study at Pt. Bank Tabungan Negara Tbk. Cirebon Branch)" in Journal of Deed, Vol ume 5, No. 1 May 2018. url http://jurnal.unissula.ac.id/index.php/akta/article/view/2525/0 accessed on 28 October 2020

Books:

[1] H.Halim HS\& Erlies S. Nurbani. (2013). Penerapan Teori Hukum Pada Penelitian Tesis Dan Disertasi.Jakarta:Raja Grafindo Persada. 
[2] Maria S.W. Sumardjono.(1994). Pembangunan Rumah Rusun Dan Permasalahannya: Ditinjau Dari Segi Yuridis Kertas Kerja Untuk Diskusi Terbatas Development Of Indonesian Consumer Protection Act (Comparative Studi Dan Draft Evaluation).Jakarta:PT.Citra Aditya Bakti.

[3] Muhammad S. Muldjabar.(2019). Prinsip Itikad Baik Dalam Perjanjian Pengikatan Jual Beli Hak Atas Tanah: Surabaya,Media Sahabat Cendekia.

[4] Munir Fuady, Hukum Kontrak.(2003).Dari Sudut Pandang Bisnis,Bandung:PT.Citra Aditya Bakti.

Internet:

[1] http://alwesius.blogspot.com/2014/05/ppjb-tidak-dapat-dipakai-sebagaidasar.html accessed 29 October 2020

[2] https://notarymagazine.com/kupas-tuntas-ppjb-skmht-ht-el/ accessed on 28 October 2020

Regulation:

[1] Act No. 7 of 1992 concerning Banking

[2] Government Regulation No. 24/1997 on land registration

[3] State Gazette of the Republic of Indonesia number 42 / POJK.03 / 2017 concerning the Obligation to Prepare and Implement Bank Credit Policies for Commercial Banks 